\title{
КОМУНІКТИВНА КУЛЬТУРА ВЧИТЕЛЯ ЯК СКЛАДОВА ПЕДАГОГІЧНОЇ МАЙСТЕРНОСТІ
}

\author{
Галушка К. Р. \\ здобувач третього (освітньо-наукового) рівня вищої освіти кафедри \\ освітології та інноваційної педагогіки, Харківський національний \\ педагогічний університет імені Г. С. Сковороди, м. Харків, Україна
}

У статті визначено і проаналізовано основні складові підготовки педагога до заняття з точки зору публічного виступу. Визначені етапи формування у педагога базових знань з ораторської майстерності. У зв'язку з иим у статті проаналізовано формування риторичної майстерності педагога. Визначені головні інструменти творення креативної та харизматичної особистості-педагога. Акиентується тема не лише мовленнєвого етикету, але головним чином йде мова про стиль мовлення педагога, володіння ним невербальними засобами спілкування (мімікою, жестами, темпом мовлення, тембром голосу).

Ключові слова: риторика, ораторська майстерність, жестикуляиія, педагог-ритор.

The article identifies and analyzes the main components of teacher training for the lesson in terms of public speaking. The stages of formation of the teacher's basic knowledge of public speaking skills are determined. In this regard, the article analyzes the formation of rhetorical skills of the teacher. The main tools for creating a creative and charismatic personalityteacher are identified. The emphasis is not only on the topic of speech etiquette, but mainly on the style of speech of the teacher, his mastery of non-verbal means of communication (facial expressions, gestures, speech rate, tone of voice).

Key words: rhetoric, oratory, gestures, teacher-rhetorician.

Педагогічна діяльність потребує від викладача певних знань у галузі ораторської майстерності. Заздалегідь продумана та підготовлена різноманітність прийомів і форм навчання мають вирішальний вплив на формування пізнавального інтересу до предмету. Викладання перед учнями або студентами - це публічний виступ. Педагог повинен уміти виголошувати промову перед аудиторією: говорити логічно, зрозуміло, цікаво і переконливо.

Під ораторським мистецтвом розуміється комплекс знань та умінь оратора, спрямований на підготовку та виголошення публічної промови: це вміння формулювати тезу і підбирати матеріал, мистецтво 
побудови своєї промови і публічного мовлення 3 метою впливу на слухачів; це вміння доводити і спростовувати, вміння переконувати; це мовна майстерність.

Педагогічна професія вимагає високого рівня навичок переконання. Педагог-ритор впливає на учнів своєю унікальністю, харизмою, словом. Сьогодні, для оптимального спілкування, впливу і взаємодії 3 аудиторією, необхідні такі складові риторичної майстерності, як: емоційне переконання, об'єднання ритора й аудиторії в загальному емоційному полі. Таким чином, це і $є$ показниками професійної комунікативної компетенції педагога.

Педагог - це особистість, яка має власну точку зору, своє світоуявлення. Він повинен мати свої індивідуальні способи активізації уваги і мислення слухачів: звертати студентів до власного життєвого досвіду, або присутніх в аудиторії; мати розширені рекомендації по темі виступу, мати компетентні джерела інформації; власний оригінальний коментар до першоджерел; визначати мету спільної з аудиторією роботи; імпровізувати та формулювати судження; мати відкриту, щиру манеру спілкування.

Зазначимо, що педагогу-оратору необхідно бути пластично розкутим при реалізації інформаційно-мовного впливу: відкритість пози; баланс динаміки, статики і семіотики пози; розрізняти жестикуляцію психологічну, дидактичну і описову; у голосі за необхідності дотримуватися мелодійності, гармонійності, скоординованості. У своїй промові логічно вміти конструювати зміст інформаційно-мовної дії; окремих фраз; уміти дотримуватися логіки у вибудовуванні послідовності «теза - аргумент - ілюстрація» і «ілюстрація — аргумент - теза»; повторювати основні тези матеріалу для запам'ятовування основних положень аудиторією; вміти логічно та чітко ставити риторичні та проблемні питання.

Експресивні вміння педагога потребують образності висловлювань; інтонаційної виразності; порівнянь і аналогій при поясненні матеріалу, чи окремих ситуацій - інтонаційна різноманітність мови як умова активізації емоційної забарвленості змісту інформаційно-мовної дії.

Головне, що треба усвідомити педагогу задля успішного виступу: важливий не тільки зміст лекції, а як саме вона презентується, доповідається. За статистикою, проведеними опитуваннями можна підвести підсумок того, що учню важливий не тільки зміст, але головне як 
доповідається матеріал. Можна сформулювати педагогічне завдання таким чином, що головна мета не донести матеріал уроку, а зробити перш за все так, щоб предмет став цікавим для самого учня, змотивувати його на подальшу роботу та отримання знань.

На відміну від представників інших професій, педагог повинен володіти мовою як основним засобом впливу на особистість учнів. 3 огляду на це, мова вчителя повинна відповідати певним вимогам. Мова повинна бути: змістовною і емоційною, за звучанням рівною, приємною на слух і відповідати вимогам акустики; мова повинна виконувати комунікативну, інтерактивну функції одночасно, повинна допомагати педагогу в проблемних ситуаціях, активізувати учнів, а не пригнічувати їх. Простота і відповідальність, природність і доброзичливе ставлення до учнів, комунікабельність — всі ці якості проявляються по-різному, в залежності від індивідуальності педагога.

У процесі роботи педагог повинен користуватися літературною мовою, його вимова має відповідати нормам фонетики і дикції, а також вимогам слухання, читання і говоріння. Треба проводити самоаналіз власного виступу, щоб зрозуміти власні мовні недоліки і виправляти їх. Значимість мовних здібностей для педагога дуже велика, оскільки він повинен за допомогою мови і за допомогою міміки і жестів вміти точно виражати свої думки і наміри.

У процесі проведення занять мова вчителя повинна бути спрямована на учнів, повинна сприяти розвитку їх інтересу до теми уроку, обговорюваних питань — тільки тоді зміст навчального матеріалу буде доступний учням.

Публічний виступ завжди має свою композицію. Потрібно вчитися вибудовувати композицію, свої думки і готувати доповідь таким чином, щоб педагогу самому було цікаво все презентувати. У якісному тексті повинні бути зав'язка, інтрига, кульмінація і меседж. Логіка мови - це основа драматургії. Але яким би чином не була підготовлена сама промова, необхідно добре розуміти основні елементи ораторської майстерності. Навіть ті, що не стосуються власне правильної вимови, структури та композицїі виступу.

Перше та головне. Педагогу необхідно бути джерелом енергії для своїх учнів. Заходячи в клас, потрібно пам'ятати, що саме власний ентузіазм викладача найбільше впливає на учнів. Під час заняття повинен відбуватися енергетичний взаємообмін педагога та учнів. 
Знання особливостей учнів, класу — ще один момент підготовки педагога до заняття. Необхідно знаходите особливий підхід до кожного класу. Якщо вас чекає публічний виступ, то варто дізнатися специфіку аудиторії, щоб наводити приклади, які будуть близькі і зрозумілі, завжди мати в голові заготовлену відповідь на питання «Навіщо нам це знати?» і подумки відповідати на нього.

Основний елемент ораторської майстерності - зоровий контакт. Саме через нього транслюється впевненість педагога як оратора. Поперше, дивитися потрібно в очі учням. Ідеальний варіант - дивитися на конкретних людей, затримувати погляд на кожному з них декілька секунд, щоб встигнути повністю вимовити якусь фразу. Особливо діти зчитують невербальні ознаки невпевненості, тому доцільно уникати таких моментів і вести себе спокійно та природно. Всі повинні відразу зрозуміти: урок почався. Краще за все почати урок-заняття з добре відомої фрази, яка моментально змотивує слухати педагога далі. У будь-якому випадку, початок уроку або лекції повинен бути чітким, зрозумілим і, по-можливості, мотивуючим.

Педагог не повинен виступати перед учнями, він повинен 3 ними спілкуватися. Будь-яка лекція набагато краще засвоюється у вигляді дискусії або бесіди. Ще краще, якщо на початку заняття ви ставите проблему і по ходу уроку намагаєтеся їі вирішити. Звісно, що одні знання з ораторської майстерності не допоможуть педагогу відразу зробити свою лекцію максимально захоплюючою. Потрібна практика, власний досвід, помилки, щоб знати як їх можна вирішувати, але знання риторики та інструментів ораторської майстерності значно полегшують педагогу розуміння підготовки до публічного виступу - цікавого уроку, мотивуючої лекції.

\section{Список використаних джерел:}

1. Сербенська О. Культура усного мовлення: практикум: навч. пос. Київ : Центр навчальної літератури, 2004. 216 с.

2. Спанатій Л. С. Риторика: навчальний посібник для студентів вищих навчальних закладів. Київ : Ін Юре, 2008. 144 с.

3. Хоменко I. В. Еристика: підручник. Київ : Центр учбової літератури, 2008. $280 \mathrm{c}$.

4. Чибісова Н. Г., Тарасова О. І. Риторика. Київ : Центр навчальної літератури, 2003. 228 с. 